\title{
The effect of the traffic organization method at a controlled intersection on the uniformity of traffic capacity
}

\author{
Roman Andronov ${ }^{1, *}$, Evgeny Leverents ${ }^{1}$, Dmitrii Genze ${ }^{1}$, and Elena Legostaeva ${ }^{1}$ \\ ${ }^{1}$ Industrial University of Tyumen, 625000 Tyumen, Russia
}

\begin{abstract}
The uniformity issues of the traffic capacity indicator of controlled intersections are considered in the article from the standpoint of the traffic management features. The necessity of knowing the traffic capacity uniformity (in addition to its size) for the traffic management and optimization purposes is shown. This indicator is measured by standard deviation or variation coefficient. Traffic patterns in which hindrances from turning vehicles and pedestrian traffic in one phase reduce the uniformity of capacity are presented. Because of this, the efficiency of signal control decreases, and the queue length and the overall delays of vehicles increase. The article distinguishes 3 patterns of traffic management at a controlled intersection in terms of hindrances caused by the movement of pedestrians and turning flows, affecting the uniformity indicator. The conclusions of the article are confirmed by conducting a multifactorial experiment with finding statistically significant coefficients.
\end{abstract}

\section{Introduction}

Each state or group of states (EU) has its own methodologies for determining the traffic capacity of automobile streets and roads and intersections on them, both controlled and uncontrolled. These methodologies are enshrined in the relevant regulatory documents $[1,2,3,4]$. An application feature of these methodologies is mostly a deterministic approach to defining capacity as a conditionally constant indicator. In the general calculation, the duration of the permitting phase and the traffic light cycle, the number of lanes, the presence of pedestrians, left-hand and right-hand traffic, the traffic flow composition, the slope of the roadway, etc. are taken into account. All of the above-mentioned factors are taken into account as adjustment factors to the so-called reference capacity (saturation flow). Norms [2] also take into account the length of the queue, which may accumulate before intersection. Indicators of capacity dissimilation (unevenness) are not taken into account or poorly considered. In [1], recommendations for a general capacity increase are given, indirectly implemented through an increase in its uniformity. These recommendations are, for example, prohibition of left turns and increasing the total cycle period with a decrease in the proportion of intermediate cycles.

* Corresponding author: aroma77777@mail.ru 
According to preliminary observations, the uneven intersection traffic capacity leads not only to a general decrease in traffic capacity, but also to an increase in traffic uncertainty. This also leads to an increase in the number of maneuvers in the traffic flow, reduced traffic safety, increased delays and increased transport losses. This instability of the traffic flow is difficult to calculate using deterministic methods, and transport modeling software systems such as VISSIM are best suited for this.

For the purposes of traffic management and its optimization, it is necessary to know the traffic capacity dissimilation of the controlled intersections for various traffic management schemes and in combination with other factors, such as the number of lanes and traffic control parameters. The result of this will be further used in the model of controlled intersection with adaptive control [6].

\section{Materials and methods}

It is proposed to monitor (an uncontrolled experiment) a sample of controlled intersections with different traffic management schemes to assess the actual capacity according to traffic light cycles and its standard deviation (variability index).

The intersection traffic capacity is proposed to be presented as a random variable, with a mathematical expectation and its standard deviation. The second indicator will evaluate the dissimilation (unevenness) of capacity.

Based on the obtained observational data, a multifactorial experiment will be conducted in order to determine the presence of a correlation between the parameters of traffic lights, the number of lanes and traffic patterns for uniform traffic capacity. The obtained indicators will be evaluated from the position of reliability and statistical significance. The analytical dependence model of the result on the initial data will be enunciated.

\section{Experiment}

In order to assess the uniformity (homogeneity) of capacity by standard deviation or by the variability index, a fairly simple linear model of the dependence was proposed in the study:

$$
y=a_{0}+a_{1} x_{1}+a_{2} x_{2}+\ldots+a_{n} x_{n}
$$

where $a_{n}$ are the indicators determined in the study; index).

$\mathrm{x}_{\mathrm{n}}-\mathrm{a}$ set of factors affecting uniformity indicators (standard deviation or variability

The selection of a linear function is based on its relative simplicity. Also, functions of a linear form are used in various methods for finding capacity based on a saturation stream [4].

For the research, a sample of 15 controlled intersections in the city of Tyumen was selected with various parameters of the cycle period, the time of enabled release signal, the number of lanes in front of the stop line, and different traffic management schemes at the junction [5]. Actual capacity was defined as the number of cars that traveled during the release phase of the traffic light, provided that there is a remainder of the cars that have not passed the intersection.

Preventions according to the traffic management scheme on them were divided into the following 3 groups:

1) Intersections in which turning directions and pedestrian traffic are prohibited or highlighted in separate phases;

2) Intersections in which only left-turning directions are highlighted in separate phases or are prohibited; 
3) Intersections in which the turning directions and the movement of pedestrians are carried out in a common stream without prohibiting a left turn.

The division into 3 groups was based on objective factors that, in the absence of significant hindrances, the uniformity of the throughput will be greatest (the variation index is minimal). When pedestrians move in one phase, hindrances will occur for right-handed directions, reducing uniformity. For the 3rd group, hindrances from left-hand traffic of vehicles in the main phase will create the greatest uncertainties in the capacity parameter and its uniformity (Figure 1).

Despite the fact that the composition of the traffic flow and the number (percentage) of cars turning at the intersection also affect the uniformity of capacity, there is some simplification made in the study. According to the fundamental Lyapunov theorem of probability theory, when more statistics are accumulated without dividing it according to the set of influencing factors, the result is a normal distribution of a random variable [5]. This is done with the purpose of further processing the results of the experiment, because most of these methods of processing the results are based on the normal (according to the Gauss curve) nature of the deviations of the experimental values from the average.

In the process of assessing the representativeness of the sample, it turned out that for a reliability of $95 \%$, within the framework of the permissible error for the results of $10 \%$ of the average, it is necessary to make 12 to 35 measurements at each junction.

Table 1. Work parameters of the considered intersection sample

\begin{tabular}{|c|c|c|c|c|c|c|}
\hline Intersection name & $\begin{array}{l}\text { Observed cross } \\
\text { section of the } \\
\text { stop line }\end{array}$ & $\begin{array}{l}\text { Number } \\
\text { of lanes }\end{array}$ & $\begin{array}{l}\text { Cycle } \\
\text { time, sec }\end{array}$ & $\begin{array}{l}\text { Release } \\
\text { phase } \\
\text { period, } \\
\text { sec }\end{array}$ & $\begin{array}{l}\text { Average } \\
\text { capacity, } \\
\text { auto/phase }\end{array}$ & $\begin{array}{l}\text { Group } \\
\text { of } \\
\text { intersect } \\
\text { ions }\end{array}$ \\
\hline $\begin{array}{l}\text { Melnikaite - } \\
\text { Respubliki }\end{array}$ & ul. Respubliki & 2 & 90 & 40 & 21.8 & 3 \\
\hline $\begin{array}{l}\text { Gertsena - } \\
\text { Pervomaiskaia }\end{array}$ & Gertsena & 2 & 71 & 30 & 17.6 & 3 \\
\hline \multirow{2}{*}{$\begin{array}{l}50 \text { let Oktiabria - } \\
\text { M.Gorkogo }\end{array}$} & $\begin{array}{l}50 \text { let Oktiabria } \\
\text { (1st direction) }\end{array}$ & 4 & 88 & 40 & 45.9 & 2 \\
\hline & $\begin{array}{l}50 \text { let Oktiabria } \\
\text { (2nd direction) }\end{array}$ & 4 & 88 & 40 & 36.5 & 2 \\
\hline \multirow{3}{*}{$\begin{array}{l}50 \text { let Oktiabria - } \\
\text { Profsoiuznaia }\end{array}$} & 50 let Oktiabria & 4 & 90 & 31 & 50.2 & 1 \\
\hline & Osipenko & 4 & 90 & 17 & 31.1 & 1 \\
\hline & Profsoiuznaia & 4 & 90 & 13 & 25.3 & 1 \\
\hline \multirow{3}{*}{$\begin{array}{l}\text { Respubliki - } \\
\text { Cheliuskintsev }\end{array}$} & $\begin{array}{l}\text { Cheliuskintsev } \\
\text { (1st direction) }\end{array}$ & 2 & 68 & 34 & 21.7 & 2 \\
\hline & $\begin{array}{l}\text { Cheliuskintsev } \\
\text { (2nd direction) }\end{array}$ & 2 & 68 & 34 & 15.2 & 3 \\
\hline & Respubliki & 2 & 102 & 51 & 22.0 & 2 \\
\hline Respubliki - M.Toreza & Respubliki & 2 & 95 & 35 & 29 & 1 \\
\hline $\begin{array}{ll}\text { Respubliki } & - \\
\text { M.Gorkogo } & \\
\end{array}$ & M.Gorkogo & 2 & 45 & 16 & 15.7 & 1 \\
\hline \multirow{2}{*}{$\begin{array}{l}50 \text { let Oktiabria - } \\
\text { Odesskaia }\end{array}$} & 50 let Oktiabria & 4 & 90 & 34 & 51.1 & 1 \\
\hline & Odesskaia & 2 & 90 & 15 & 13.9 & 2 \\
\hline $\begin{array}{ll}\text { Akkumuliatornaia } & - \\
\text { Iamskaia } & \\
\end{array}$ & $\begin{array}{l}\text { Akkumuliatorna } \\
\text { ia }\end{array}$ & 2 & 75 & 28 & 10.9 & 3 \\
\hline
\end{tabular}

Further, according to the data obtained as a result of the experiment, an experiment matrix was compiled with an assessment of the effect of each factor on the final value, with a reliability assessment of each indicator and discarding statistically insignificant values. 
Despite the fact that the traffic capacity depends on many of the above parameters, it is convenient for us to put it on a par with factors (actual capacity) that affect the uniformity parameter (standard deviation or variability index).

\section{$4 \quad$ Results and discussion}

When compiling a matrix of the results of the experiment and assessing the influence of each factor, 4 factors were selected that could affect the traffic uniformity. It is proposed to consider the following factors:

$\mathrm{a}_{0}$ - the constant of the linear function;

$\mathrm{a}_{1}$ - the number of lanes;

$\mathrm{a}_{2}-$ the intersection group;

$\mathrm{a}_{3}$ - actual capacity, auto/phase.

In the model, it was proposed not to take into account the duration of the cycle and the release phase of the traffic light, because it is more convenient to work with capacity indicators without reference to time (auto/phase) when processing the model. This is due to the fact that during the resolving phase a stable continuous flow of cars is formed, and the dissimilation of the throughput is manifested precisely in the different actual number of cars that managed to pass through the intersection during the release signal period.

The final experimental data are shown in table 2 .

Table 2. The analysis results of the traffic flow approaching to intersections for the correlation between the main parameters

\begin{tabular}{|c|c|c|c|c|}
\hline Intersection name & $\begin{array}{l}\text { Observed cross } \\
\text { section of the } \\
\text { stop line }\end{array}$ & $\begin{array}{l}\text { Traffic capacity } \\
\text { for the lane, } \\
\text { auto/hour }\end{array}$ & $\begin{array}{l}\text { Standard capacity } \\
\text { deviation }\end{array}$ & $\begin{array}{l}\text { Variability } \\
\text { index, } \\
\%\end{array}$ \\
\hline $\begin{array}{l}\text { Melnikaite - } \\
\text { Respubliki }\end{array}$ & ul. Respubliki & 435 & 5.23 & 24 \\
\hline $\begin{array}{l}\text { Gertsena - } \\
\text { Pervomaiskaia }\end{array}$ & Gertsena & 446 & 3.87 & 22 \\
\hline \multirow{2}{*}{$\begin{array}{l}50 \text { let Oktiabria - } \\
\text { M.Gorkogo }\end{array}$} & $\begin{array}{l}50 \text { let Oktiabria } \\
\text { (1st direction) }\end{array}$ & 469 & 6.89 & 15 \\
\hline & $\begin{array}{l}50 \text { let Oktiabria } \\
\text { (2nd direction) }\end{array}$ & 373 & 5.11 & 14 \\
\hline \multirow{3}{*}{$\begin{array}{l}50 \text { let Oktiabria - } \\
\text { Profsoiuznaia }\end{array}$} & 50 let Oktiabria & 502 & 4.52 & 9 \\
\hline & Osipenko & 311 & 3.73 & 12 \\
\hline & Profsoiuznaia & 254 & 3.29 & 13 \\
\hline \multirow{3}{*}{$\begin{array}{l}\text { Respubliki - } \\
\text { Cheliuskintsev }\end{array}$} & $\begin{array}{l}\text { Cheliuskintsev } \\
\text { (1st direction) }\end{array}$ & 574 & 3.04 & 14 \\
\hline & $\begin{array}{l}\text { Cheliuskintsev } \\
\text { (2nd direction) }\end{array}$ & 402 & 3.04 & 20 \\
\hline & Respubliki & 388 & 4.84 & 22 \\
\hline Respubliki - M.Toreza & Respubliki & 549 & 2.32 & 8 \\
\hline $\begin{array}{ll}\text { Respubliki } & - \\
\text { M.Gorkogo }\end{array}$ & M.Gorkogo & 628 & 1.41 & 9 \\
\hline \multirow{2}{*}{$\begin{array}{l}50 \text { let Oktiabria - } \\
\text { Odesskaia }\end{array}$} & 50 let Oktiabria & 511 & 6.13 & 12 \\
\hline & Odesskaia & 278 & 1.53 & 11 \\
\hline $\begin{array}{l}\text { Akkumuliatornaia } \\
\text { Iamskaia }\end{array}$ & $\begin{array}{l}\text { Akkumuliatorna } \\
\text { ia }\end{array}$ & 262 & 2.51 & 23 \\
\hline
\end{tabular}

For convenient perception of the experimental results, data on the dissimilation of the actual capacity, expressed in terms of the variability index, are shown in Figure 1. 
When processing the results of the experiment, each parameter was checked for statistical significance according to the Student test (tables 3-10). A probability of $95 \%$ is taken as a confidence probability.

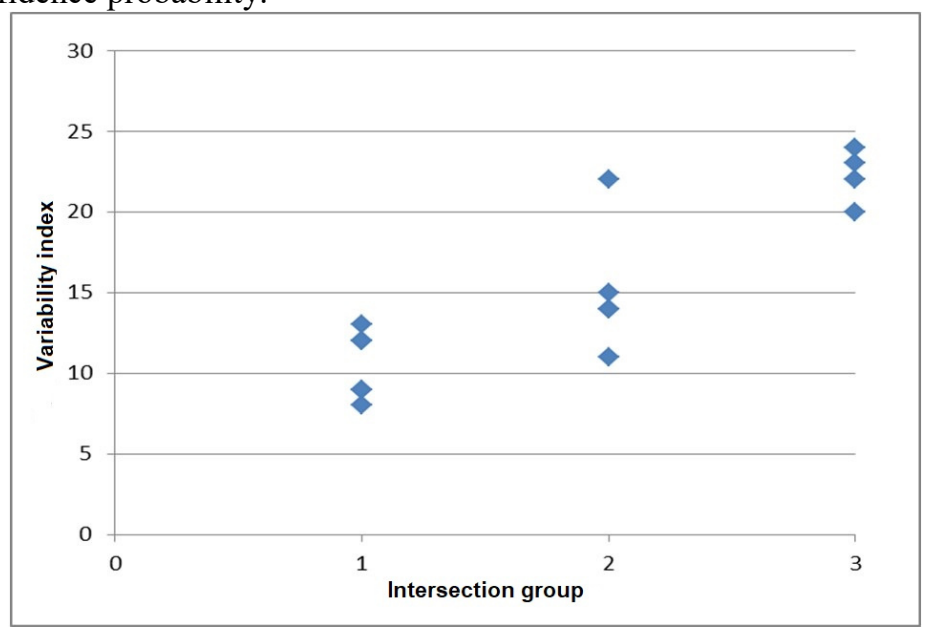

Fig. 1. A graph of the dependence of the variability index in capacity on the traffic management at intersections

Table 3. Statistical significance verification of the coefficients $a_{0}, a_{1}, a_{2}, a_{3}(y-$ standard deviation)

\begin{tabular}{|l|c|c|c|}
\hline Model coefficient & Coefficient value & Confidence interval & Relative confidence interval \\
\hline $\mathrm{a}_{0}$ & -2.279271 & \pm 2.500355 & $-110 \%$ \\
\hline $\mathrm{a}_{1}$ & 0.2511102 & \pm 0.822893 & $328 \%$ \\
\hline $\mathbf{a}_{2}$ & $\mathbf{1 . 2 2 8 8 1 0 8}$ & $\pm \mathbf{0 . 6 8 0 3 4 7}$ & $\mathbf{5 5 \%}$ \\
\hline $\mathbf{a}_{3}$ & $\mathbf{0 . 1 1 4 4 7 1}$ & $\pm \mathbf{0 . 0 6 2 6 8 4}$ & $\mathbf{5 5 \%}$ \\
\hline
\end{tabular}

Table 4. Statistical significance verification of the coefficients $a_{0}, a_{1}, a_{2}, a_{3}$ (y-variability indicator)

\begin{tabular}{|l|c|c|c|}
\hline Model coefficient & Coefficient value & Confidence interval & Relative confidence interval \\
\hline $\mathrm{a}_{0}$ & 2.6351032 & \pm 9.406228 & $357 \%$ \\
\hline $\mathrm{a}_{1}$ & 0.7351052 & \pm 3.095688 & $421 \%$ \\
\hline $\mathbf{a}_{2}$ & $\mathbf{6 . 0 3 9 0 1 1 8}$ & $\pm \mathbf{2 . 5 5 9 4 3 5}$ & $\mathbf{4 2 \%}$ \\
\hline $\mathrm{a}_{3}$ & -0.028177 & \pm 0.235815 & $-837 \%$ \\
\hline
\end{tabular}

An analysis of the data in Tables 3 and 4 shows that the indicators $a_{0}$ and $a_{1}$ are statistically insignificant in both cases, and in the second case also $a_{3}$. This preliminary suggests that the constant of the linear function and the number of lanes can be neglected in the model. The statistical insignificance of the indicator describing the street lane is caused by the fact that the number of lanes is indirectly included in the $\mathrm{a}_{3}$ indicator.

According to the principles of processing the experiment, these indicators could be immediately discarded. However, the significance of the above-mentioned indicators in various ratios was checked. As a result, such a formulation significantly worsened the quality of the model (presented in tables 5-8). 
Table 5. Statistical significance verification of the coefficients $a_{0}, a_{1}, a_{2}, a_{3}(y-$ standard deviation)

\begin{tabular}{|c|c|c|c|}
\hline Model coefficient & Coefficient value & Confidence interval & Relative confidence interval \\
\hline $\mathrm{a}_{0}$ & -1.880665 & \pm 2.061709 & $-110 \%$ \\
\hline $\mathbf{a}_{2}$ & $\mathbf{1 . 1 8 4 4 4 3 2}$ & $\pm \mathbf{0 . 6 4 2 7 1 1}$ & $\mathbf{5 4 \%}$ \\
\hline $\mathbf{a}_{3}$ & $\mathbf{0 . 1 2 8 7 1 4 3}$ & $\pm \mathbf{0 . 0 4 0 4 6 1}$ & $\mathbf{3 1 \%}$ \\
\hline
\end{tabular}

Table 6. Statistical significance verification of the coefficients $a_{0}, a_{1}, a_{2}, a_{3}(y-$ variability indicator)

\begin{tabular}{|c|c|c|c|}
\hline Model coefficient & Coefficient value & Confidence interval & Relative confidence interval \\
\hline $\mathrm{a}_{0}$ & 3.8019903 & \pm 7.695562 & $202 \%$ \\
\hline $\mathbf{a}_{2}$ & $\mathbf{5 . 9 0 9 1 2 9 2}$ & $\pm \mathbf{2 . 3 9 8 9 9}$ & $\mathbf{4 1 \%}$ \\
\hline $\mathrm{a}_{3}$ & 0.0135193 & \pm 0.151027 & $1117 \%$ \\
\hline
\end{tabular}

Table 7. Statistical significance verification of the coefficients $a_{0}, a_{1}, a_{2}, a_{3}(y-$ standard deviation)

\begin{tabular}{|c|c|c|c|}
\hline Model coefficient & Coefficient value & Confidence interval & Relative confidence interval \\
\hline $\mathrm{a}_{1}$ & -0.140775 & \pm 0.777249 & $-552 \%$ \\
\hline $\mathbf{a}_{2}$ & $\mathbf{0 . 7 1 1 8 1 0 1}$ & $\pm \mathbf{0 . 4 1 6 2 6 1}$ & $\mathbf{5 8 \%}$ \\
\hline $\mathbf{a}_{3}$ & $\mathbf{0 . 1 0 9 2 4 2 2}$ & $\pm \mathbf{0 . 0 6 9 1 4 5}$ & $\mathbf{6 3 \%}$ \\
\hline
\end{tabular}

Table 8. Statistical significance verification of the coefficients $a_{0}, a_{1}, a_{2}, a_{3}(y-$ variability indicator)

\begin{tabular}{|c|c|c|c|}
\hline Model coefficient & Coefficient value & Confidence interval & Relative confidence interval \\
\hline $\mathrm{a}_{1}$ & 1.18817 & \pm 2.544684 & $214 \%$ \\
\hline $\mathbf{a}_{2}$ & $\mathbf{6 . 6 3 6 7 2 4 9}$ & $\pm \mathbf{1 . 3 6 2 8 2 4}$ & $\mathbf{2 1 \%}$ \\
\hline $\mathrm{a}_{3}$ & -0.022132 & \pm 0.226377 & $-1023 \%$ \\
\hline
\end{tabular}

Table 9. Statistical significance verification of the coefficients a0, a1, a2, a3 (y-standard deviation)

\begin{tabular}{|c|c|c|c|}
\hline Model coefficient & Coefficient value & Confidence interval & Relative confidence interval \\
\hline $\mathbf{a}_{2}$ & $\mathbf{0 . 6 7 6 3 0 5 7}$ & $\pm \mathbf{0 . 3 5 2 0 8 4}$ & $\mathbf{5 2 \%}$ \\
\hline $\mathbf{a}_{3}$ & $\mathbf{0 . 0 9 7 5 5 4 9}$ & $\pm \mathbf{0 . 0 2 3 8 1 8}$ & $\mathbf{2 4 \%}$ \\
\hline
\end{tabular}

Table 10. Statistical significance verification of the coefficients $a_{0}, a_{1}, a_{2}, a_{3}(y-$ variability indicator)

\begin{tabular}{|c|c|c|c|}
\hline Model coefficient & Coefficient value & Confidence interval & Relative confidence interval \\
\hline $\mathbf{a}_{2}$ & $\mathbf{6 . 9 3 6 3 9 0 1}$ & $\pm \mathbf{1 . 1 9 3 6 7 2}$ & $\mathbf{1 7 \%}$ \\
\hline $\mathrm{a}_{3}$ & 0.0765117 & \pm 0.08075 & $106 \%$ \\
\hline
\end{tabular}

The best quality model was obtained according the results of the model presented in table 9. The final dependence function of the standard deviation $y$ will be as follows:

$$
y=0,6763 x_{1}+0,09755 x_{2}
$$

where $\mathrm{x}_{1}$ is the intersection group by the method of traffic management; $\mathrm{x}_{2}$ is the value of the actual capacity (auto/phase).

\section{References}

1. Handbuch für die Bemessung von Straßenverkehrsanlagen (HBS 2001), Forschungsgesellschaft für Straßen- und Verkehrswesen (Hrsg.), Nr. 299, FGSV Verlag GmbH, Köln (2001) 
2. Highway Capacity Manual (HCM 2000). TRB, National Research Council, Washington,D.C., (2000).

3. Canadian Capacity Guide for Signalized Intersections, Institute of Transportation Engineers District 7 - Canada, Third Edition, (2008)

4. ODM 218.2.020-2012. Metodicheskie rekomendatsii po otsenke propusknoi sposobnosti avtomobilnykh dorog. - M: ROSAVTODOR, (2012)

5. R.V. Andronov, Modeling of queues at regulated street intersections in a large city within the dense traffic, Tyumen (2007)

6. N. Metropolis, S. Ulam, JASA 44, 247 (1949)

7. R. Andronov, E. Leverents. MATEC Web of Conferences (2018).

8. S. Sinha, 8th International Conference on Communication Systems and Networks (COMSNETS) Proceedings 15872477 (2016)

9. ODM 218.6.003-2011. Metodicheskie rekomendatsii po proektirovaniiu svetofornykh obieektov na avtomobilnykh dorogakh (2013)

10. M.M. Bekmagambetov, A.V. Kochetkov Journal of Automotive Engineers. 6. 25-34. (2012)

11. L.S. Didkovskaya World Science. (2014). 